\title{
Mismatch Negativity in Children: Reference Values
}

\author{
Dulce Azevedo Ferreira ${ }^{1} \quad$ Claudine Devicari Bueno $^{1}$ Sady Selaimen de Costa ${ }^{2}$ Pricila Sleifer $^{1}$ \\ 1 Department of Human Health and Communication, Universidade \\ Federal do Rio Grande do Sul, Porto Alegre, RS, Brazil \\ 2 Department of Ophthalmology and Otorhinolaringology, \\ Universidade Federal do Rio Grande do Sul, Porto Alegre, RS, Brazil \\ Address for correspondence Dulce Azevedo Ferreira, Master, \\ Departamento de Saúde e Comunicação Humana, Universidade \\ Federal do Rio Grande do Sul, Rua Ramiro Barcelos 2600, Porto Alegre, \\ RS 90040-060, Brazil (e-mail: dulceazevedof@gmail.com).
}

Int Arch Otorhinolaryngol 2019;23:142-146.

\begin{abstract}
Introduction The Mismatch Negativity (MMN) auditory evoked potential evaluation is a promising procedure to assess objectively the ability of auditory discrimination. Objective To characterize the latency and amplitude values of MMN in children with normal auditory thresholds and without auditory complaints.

Methods Children between 5 and 11 years old participated in the present study. All participants underwent acoustic immittance measurements and tonal and vocal audiometry. The MMN was recorded with the MASBE ATC Plus system (Contronic, Pelotas, RS, Brazil). The electrodes were fixed in Fz (active electrode), Fpz (ground electrode) and in M2 and M1 (references electrodes). The intensity used was $80 \mathrm{dBHL}$, the frequent stimulus was $1,000 \mathrm{~Hz}$ and the rare stimulus was $2,000 \mathrm{~Hz}$. The stimuli were presented in both ears separately.

Results For the female group, the mean latencies and amplitude of MMN were 177.3 $\mathrm{ms}$ and $5.01 \mu \mathrm{V}$ in the right ear (RE) and $182.4 \mathrm{~ms}$ and $5.39 \mu \mathrm{V}$ in the left ear (LE). In the male group, the mean latencies were $194.4 \mathrm{~ms}$ in the RE and $183.6 \mathrm{~ms}$ in the LE, with an amplitude of $5.11 \mu \mathrm{V}$ in the RE and $5.83 \mu \mathrm{V}$ in the LE. There was no statistically

Keywords

- auditory evoked potential

- electrophysiology

- children significant difference between ears ( $p=0.867$ - latency and $p=0.178$ - amplitude), age $(p>0.20)$ and the gender of the participants $(p>0.05)$.

Conclusion Using the described protocol, the mean latency value of MMN was 184.0 $\mathrm{ms}$ for RE and $182.9 \mathrm{~ms}$ for $\mathrm{LE}$, and the amplitude was $5.05 \mu \mathrm{V}$ and $5.56 \mu \mathrm{V}$ for the left and right ears, respective.
\end{abstract}

\section{Introduction}

In audiological practice, long-latency auditory evoked potentials (AEPs) can be used as an objective measurement of cognitive processes. ${ }^{1,2}$ The great advantage of AEPs when compared with other neurocognitive methods, is the possibility of recording the neuronal activation associated with brain processing, making it possible to assess the brain areas activated during cognitive processing tasks. $^{3}$

The mismatch negativity (MMN) AEP allows the understanding of the central processes of auditory perception, of different forms of memory and attention. ${ }^{4}$ The origin process of AEPs is preattentional, ${ }^{3}$ and its main generator is the auditory cortex, with contributions from the frontal cortex, the thalamus and the hippocampus. ${ }^{5}$

Mismatch negativity is elicited by the presentation of low probability (rare) auditory stimuli that constitute a physical change from repetitive standard stimulation (frequent stimuli). This is generated automatically, regardless of the attention of the subject, ${ }^{3,6-11}$ whenever an afferent stimulus does not coincide with the sensorial representation of the repetitive stimulation presented. ${ }^{3,12}$ The MMN reflects the ability of the brain to discriminate sounds, ${ }^{13}$ auditory memory and involuntary attention. ${ }^{11}$ The MMN assessment has the benefit of having a good correlation with other assessments of auditory discrimination. ${ }^{8,13}$ received

August 7, 2017

accepted

June 2, 2018

published online

October 24, 2018
DOI https://doi.org/

10.1055/s-0038-1667313. ISSN $1809-9777$.
Copyright (e 2019 by Thieme Revinter

Publicações Ltda, Rio de Janeiro, Brazil
License terms

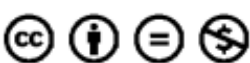


The MMN can be generated in infants, ${ }^{14}$ in children with typical development, with language and auditory processing disorders, ${ }^{15-17}$ with reading and writing disorders and dyslexia, ${ }^{17-24}$ with stuttering, ${ }^{25}$ with aphasia, ${ }^{26}$ among others. Nevertheless, despite the possibility of clinical application in the children population, it is still necessary to standardize the values of latencies and amplitudes of the MMN due to the variability in its measurements and the protocols used. ${ }^{10}$

It is believed, therefore, that normative procedures should be treated and are of great value for wider application in specific groups of children in the health field, increasing the knowledge in their accomplishment and in the interpretation of the results. Thus, in view of the possibility of applicability in the audiological practice for differential diagnosis and to contribute with the scientific literature on the findings of the MMN in children with normal hearing, the purpose of the present study was to characterize the values of the latencies and amplitudes of MMN in children with normal auditory thresholds and without otological complaints and to relate the values to the ears, gender and age of the participants.

\section{Methods}

Thirty-six Brazilian school children (22 females and 14 males) in the age group between 5 and 11 years were recruited for convenience. All the participants presented normal auditory thresholds ( $<15 \mathrm{dBHL}$ ) according to the classification proposed by Northern et $\mathrm{al}^{27}$ with an air-tobone gap $>10 \mathrm{dBHL}$. In addition, they had acoustic reflexes and type A tympanometric curves, according to the classification proposed by Jerger ${ }^{28}$. Information about schooling, learning difficulties, language, speech and hearing, as well as otological history, family history of hearing problems and/or language and manual preferences of the participants were collected. Subjects with cognitive dysfunctions, selfreported learning difficulties, and genetic or craniofacial abnormalities were excluded.

The ethical and methodological issues of the present research were approved by the Research Ethics Committee of the Research Ethics Committee of the UFRGS Institute of Psychology (process number 55977316.8.0000.5334). All the procedures of the present study were performed at the Nucleus of Studies in Electrophysiology of the Audit of the Audiology Clinic of UFRGS, after the person responsible for the child signed the informed consent form. Previous instructions were given to each child regarding each procedure that would be performed.

Initially, the external acoustic meatus was inspected with the otoscope, (Welch Allyn Inc., Skaneateles Falls, NY, USA) and, if no cerumen was present, the participant was sent to perform the exams. Acoustic immittance measurements (AIM) were searched with Impedance Audiometer AT235h (Interacoustics, Middelfart, Denmark). Static and dynamic complacencies were verified, and the curve was plotted and classified according to the Jerger classification. ${ }^{28}$ In the investigation of the ipsilateral and contralateral acoustic reflexes, the thresholds in the frequencies of $500,1,000$,
2,000 and 4,000 $\mathrm{Hz}$ in both ears were investigated. The pure tone audiometry (ATL) was performed in an acoustically treated booth with the previously calibrated HerpInventis audiometer (Inventis, Padova, Italy). The thresholds were performed by air conduction at the frequencies of 250,500 , $1,000,2,000,3,000,4,000,6,000$ and $8,000 \mathrm{~Hz}$, and by bone conduction at the frequencies of 500, 1,000, 2,000, 3,000 and $4,000 \mathrm{~Hz}$ in both ears.

After that, a speech audiometry was performed, with the percentage of speech recognition index (SRI) and speech recognition threshold (SRT). For the SRI, 25 monosyllabic words were presented at an intensity of $40 \mathrm{dBHL}$ above the tritonal average in the air conduct of $500,1,000$ and 2,000 Hz in each ear. The children were asked to repeat the words. For the SRT, the initial intensity used was also $40 \mathrm{dBHL}$ above the tritonal average, which was reduced until reaching the level of intensity in which the child could understand and repeat correctly $50 \%$ of the presented trisyllabic words.

After the peripheral auditory assessment, the children were referred to an acoustic and electrically treated room to perform the MMN assessment. The examiner cleaned the skin with a Nuprep - skin prep gel - exfoliant (Weaver and Company, Autora, CO, USA) and with gauze. Subsequently, silver electrodes were placed with Ten20 conductive electrolytic paste (Weaver and Company, Aurora, CO, USA) and Micropore surgical tape (3M, St. Paul, MN, USA). The ground electrode was placed on the front (Fpz) and the active electrode at Fpz, close to the scalp. The reference electrode was positioned on the right (M2) and on the left (M1) mastoids. The earphones EarTone 3A/5A (Contronic, Pelotas, RS, Brazil) were placed on both ears. For the test, the MASBE ATC Plus system (Contronic, Pelotas, RS, Brazil) was used. The electrical impedance was maintained below $5 \Omega$ in each lead and the difference between the 3 electrodes did not exceed $2 \Omega$.

After the impedance check, an electroencephalogram (EEG) scan was performed to verify the spontaneous brain electrical activity and to verify artifacts that might interfere in the MMN. The children were instructed to not hold their limbs and to not cross their legs and arms during the procedure.

For the MMN recording, standard stimuli were presented with short interstimulus interval and were being intercalated by stimuli that differ in frequency (rare/deviant stimulus).

In relation to the parameters used to register the MMN, the auditory stimuli were presented in monaural mode, first in the left ear (LE) and then in the right ear (RE), with a frequency of $1,000 \mathrm{~Hz}$ ( 50 cycles) for the standard stimulus and $2,000 \mathrm{~Hz}$ (50 cycles) for the deviant stimulus, at an intensity of $80 \mathrm{dBHL}$ for standard and deviant stimuli. The equipment allowed 2,000 premeditations and the oddball paradigm used was $90 / 10$, with alternate polarity. In the acquisition, the full scale was $200 \mu \mathrm{V}$, with a high pass filter of $1 \mathrm{~Hz}$, low pass filter of $20 \mathrm{~Hz}$, Notch of $60 \mathrm{~Hz}$ - YES, 90\% noise limit, time window of $500 \mathrm{~ms}$, and amplitude of the trace up to $7.5 \mu \mathrm{V}$. It should be noted that, to guarantee a greater reliability in the analyzes, all electrophysiological records were analyzed by two different evaluators at different times and two collections were performed in each ear to allow the reproducibility of traces. 
The results were organized as descriptive statistics, in which the quantitative variables were described by average, standard deviation (SD) and amplitude of variation. The qualitative variables were described by absolute and relative frequencies. To compare the ears in relation to the latency and amplitude results, the t-student test for paired samples was applied. In the comparison of averages between genders, the t-student test for independent samples was applied. The association of latency and amplitude results with age was assessed by the Pearson correlation coefficient.

The significance level adopted was $5 \%(p<0.05)$ and the analyzes were performed in the SPSS software version 21.0 (IBM Corp., Armonk, NY, USA).

\section{Results}

The study consisted of 41 children. Five of them, who did not complete all the proposed procedures, were excluded. Thus, the results refer to a sample of 36 participants. Characterization data of the sample are described in -Table $\mathbf{1}$.

All the children presented MMN, and no participant had to be excluded. There was no statistically significant difference in the comparison between the average of the latencies and amplitudes between the RE and the LE, indicating that the RE and the LE presented equivalent values of latency and amplitude. - Table 2 shows the values of the latencies and amplitudes of MMN in both ears.

No statistically significant differences were found in the comparison of the values of latencies and amplitudes of the MMN between genders (-Table 3). In this way, in the present research, there is no evidence that the latency and amplitude values of children are influenced by their gender.

Table 1 Sample characterization

\begin{tabular}{|l|l|}
\hline Variables & $n=36$ \\
\hline $\begin{array}{l}\text { Age (years) - average } \pm \text { SD } \\
{[\text { min - max }]}\end{array}$ & $8.00 \pm 2.11[5-11]$ \\
\hline Gender $-n(\%)$ & $14(38.9)$ \\
\hline Male & $22(61.1)$ \\
\hline Female &
\end{tabular}

Abbreviations: max, maximum; min, minimum; SD, standard deviation.

Table 2 Comparison between ears

\begin{tabular}{|l|l|l|l|}
\hline Variables & Right ear & Left ear & \multirow{2}{*}{$\boldsymbol{p}^{*}$} \\
\cline { 2 - 3 } & $\begin{array}{l}\text { Average } \pm \text { SD } \\
\text { [min-max] }\end{array}$ & $\begin{array}{l}\text { Average } \pm \text { SD } \\
{[\text { min-max] }}\end{array}$ & \\
\hline $\begin{array}{l}\text { Latency } \\
(\mathrm{ms})\end{array}$ & $\begin{array}{l}184.0 \pm 43.4 \\
{[116.5-317.04]}\end{array}$ & $\begin{array}{l}182.9 \pm 37.9 \\
{[113.95-269,45]}\end{array}$ & 0.867 \\
\hline $\begin{array}{l}\text { Amplitude } \\
(\mu \mathrm{V})\end{array}$ & $\begin{array}{l}5.05 \pm 1.76 \\
{[1.32-8.73]}\end{array}$ & $\begin{array}{l}5.56 \pm 2.42 \\
{[1.05-11.83]}\end{array}$ & 0.178 \\
\hline
\end{tabular}

Abbreviations: $\mu \mathrm{V}$, amplitude; max, maximum; min, minimum; ms, milliseconds; SD, standard deviation.

${ }^{*}$ t-student test for paired data.
Table 3 Comparison between genders

\begin{tabular}{|l|l|l|l|}
\hline Variables & $\begin{array}{l}\text { Male } \\
(\boldsymbol{n}=\mathbf{1 4})\end{array}$ & $\begin{array}{l}\text { Female } \\
(\boldsymbol{n}=\mathbf{2 2})\end{array}$ & \multirow{2}{*}{} \\
\cline { 2 - 3 } & Average \pm SD & Average \pm SD & \\
\hline \multicolumn{3}{|l|}{ Latency $(\mathrm{ms})$} & \\
\hline Right ear & $194.4 \pm 53.6$ & $177.3 \pm 35.3$ & 0.257 \\
\hline Left ear & $183.6 \pm 37.5$ & $182.4 \pm 39.0$ & 0.928 \\
\hline Amplitude $(\mu \mathrm{V})$ & $5.11 \pm 2.01$ & $5.01 \pm 1.62$ & 0.868 \\
\hline \multicolumn{2}{|l|}{ Right ear } & $5.11 \pm 2.67$ & 0.603 \\
\hline Left ear & $5.83 \pm 2.04$ & $5.39 \pm 2.67$ \\
\hline
\end{tabular}

Abbreviations: $\mu \mathrm{V}$, amplitude; ms, milliseconds; $S \mathrm{D}$, standard deviation. *t-student test for paired data.

\section{Discussion}

To estimate the standardized effect size of 0.9 , a sample size of 36 individuals was calculated. A significance of 0.05 was accepted with $90 \%$ confidence interval $(\mathrm{CI})$. The data analysis was performed with the Epilnfo (Centers for Disease Control and Prevention, Atlanta, GA, USA)) and the STATCAL (Prana Ungiana Gio, Indonesia) software. It is pointed out in the literature that the responses of MMN present a high level of unsystematic variation. Therefore, it is recommended that a large number of subjects should be measured to allow significant differences between the control group and the study group. ${ }^{29}$ It is observed that most of the studies with control group present a reduced number of children in their samples. $^{15,16,19,20,23-26,30-33}$ It should be emphasized that the casuistry of the present research is larger than others found in the scientific literature, but researches with different age groups and larger groups are necessary.

The parameter used to elicit the MMN potential was the oddball paradigm with tone burst with difference between frequencies. The frequent stimulus was set at1,000 $\mathrm{Hz}$ and the rare stimulus was set at $2,000 \mathrm{~Hz}$. It is recommended that large differences between stimuli be avoided so that a P3 component does not overlap the response, thereby compromising the recording of the MMN. ${ }^{3}$ Although the difference in the present study is greater than $10 \%$, all children present the MMN potential, as well as in a normative study conducted in an adult population with the same parameters. ${ }^{12}$

It is pointed out that, if applied to the same child in a retest situation, the tone burst stimulus is more reliable when compared with the speech stimulus when applied to the same child in a retest situation. ${ }^{29}$ Likewise, the choice of stimulus and task conditions influences the replicability of the $\mathrm{MMN}^{34}$ as well as the characteristics of their appearance. ${ }^{11}$ It can be seen, however, that the tone burst stimulus is highly used in national and international studies with children. ${ }^{16,18,19,25,26,30,35-41}$

The mean values of the MMN latencies in children with normal hearing were $184 \mathrm{~ms}$ in the RE and $182.9 \mathrm{~ms}$ in the LE) The mean amplitude verified was $5.05 \mu \mathrm{V}$ in the RE and $5.56 \mu \mathrm{V}$ in the LE.

The latency of the AEP shows the time course of the electrophysiological activity ${ }^{10}$ and its values for the children 
population are higher than those found in adults, ${ }^{12}$ since the maturation process of the auditory pathway interferes with the values of latency and amplitude in different age groups. $^{42}$ Regarding the values found the present this study, similar results were found in children without specific alterations, described in the national and international literature, where the MMN appears between 150 and 300 ms, ${ }^{16,17,21,26,30,31,35-37,42-44}$ regardless of the stimulus used and the position of the electrodes. The MMN can be obtained in children in latencies $\leq 350 \mathrm{~ms}^{33,45}$ In addition, studies with children and adults did not identify differences in latencies and amplitudes between the ears tested. ${ }^{12,19,30,46}$

The MMN amplitude demonstrates the extent of neural allocation involved in the cognitive processes. ${ }^{10}$ Regarding the amplitude, the literature recommends values of approximately of 0.5 to $5 \mu \mathrm{V} .{ }^{47}$ Studies show amplitudes, in general, smaller than $5 \mu \mathrm{V} .{ }^{7,13,22,26,30-32,36,37}$ However, it is reported that as the degree of discrepancy between the frequent and rare stimulus increases, the amplitude of the MMN may also increase. ${ }^{48}$ It is believed that this may be the reason why the amplitude values of the present study presented values close to the maximum amplitude described, as well as other studies reported in the literature. ${ }^{16,21,49}$

Although the age group of the present sample presented variability, children aged between 5 and 11 years old, and the literature report that the values depend on the age and the maturation process of the auditory pathway, ${ }^{13,29,42}$ there was no association of the latency and amplitude results with the age of the subjects $(p>0.20)$. This finding is in agreement with studies in the international literature ${ }^{13,29}$ that investigated the MMN in neonates and children and, likewise, did not find differences regarding the age of the participants and the amplitude of this potential. However, in latency values, a significant difference was observed in the literature when comparing full-term with preterm neonates, but this discrepancy was not found when comparing fullterm infants with 3-month-old infants. ${ }^{13}$

Similar results were found in relation to the gender of the participants. Although other studies with adults and elderly subjects demonstrate higher values of latency and amplitude in males than in females, $6,12,50$ in the present study no statistically significant differences were found between genders. These results corroborate with studies performed in neonates using long-latency potentials ${ }^{51}$ and in young adults with $\mathrm{MMN},{ }^{52}$ which similarly did not show differences between genders in the procedures performed.

Few studies describing normative values for MMN in children were found. Thus, it is believed that the present research can promote subsidies in the interpretation of MMN results, and that it can be used as reference for this potential when the same parameters are used. In addition, the present study may place researchers on future analyzes with MMN in the children population considering the variability of the range of normality, as well as bring new knowledge about the forms of application of the exam. It should be noted, however, that further scientific research with different parameters for the use of this potential in different age groups is still necessary.

\section{Conclusion}

The MMN appeared in all children who participated in the present study. No statistical differences were found for the latencies and amplitudes of the MMN in relation to the gender and age of the participants. Likewise, a similarity was verified between the ears of the the participants. Using the described protocol, the mean latency value of MMN was $184.0 \mathrm{~ms}$ for the RE and $182.9 \mathrm{~ms}$ for the LE, with minimum and maximum values of $113.95 \mathrm{~ms}$ and 317.04 $\mathrm{ms}$, respectively. Regarding the amplitude, values of $5.05 \mu \mathrm{V}$ and $5.56 \mu \mathrm{V}$ were obtained for the REs and LEs, respectively.

\section{References}

1 Didoné DD, Garcia MV, Oppitz SJ, et al. Potencial evocado auditivo P300 em adultos: valores de referência. Einstein (Sao Paulo) 2016; 14(02):208-2012

2 Melo Â, Biaggio EPV, Rechia IC, Sleifer P. Potenciais evocados auditivos corticais em neonatos nascidos a termo e pré-termo. CoDAS 2016;28(05):491-496

3 Santos MAR, Munhoz MSL, Peixoto MAL, Haase VG, Rodrigues JL, Resende LM. Contribuição do Mismatch Negativity na avaliação cognitiva de indivíduos portadores de esclerose múltipla. Rev Bras Otorrinolaringol 2006;72(06):800-807

4 Näätänen R, Paavilainen P, Rinne T, Alho K. The mismatch negativity (MMN) in basic research of central auditory processing: a review. Clin Neurophysiol 2007;118(12):2544-2590

5 Näätänen R, Astikainen P, Ruusuvirta T, Huotilainen M. Automatic auditory intelligence: an expression of the sensory-cognitive core of cognitive processes. Brain Res Brain Res Rev 2010;64(01): 123-136

6 Brossi AB, Borba KC, Garcia CFD, Reis ACMB, Isaac ML. Verificação das respostas do mismatch negativity (MMN) em sujeitos adultos normais. Rev Bras Otorrinolaringol 2007;73(06):793-802

7 Rocha-Muniz CN, Befi-Lopes DM, Schochat E. Mismatch negativity in children with specific language impairment and auditory processing disorder. Rev Bras Otorrinolaringol (Engl Ed) 2015;81 (04):408-415

8 Roggia SM. Mismatch Negativity. In: Boéchat EM, Menezes PL, Couto CM, Frizzo ACF, Scharlach RC, Anastásio ART, Eds. Tratado de Audiologia. $2^{a}$ ed. São Paulo: Santos; 2015:151-159

9 Sleifer P. Avaliação eletrofisiológica da audição em crianças. In: Cardoso MC (Org.), Fonoaudiologia na infância: avaliação e tratamento, Rio de Janeiro: Revinter; 2015:171-194

10 Romero ACL, Regacone SF, Lima DDB, Menezes PL, Frizzo ACF. Potenciais relacionados a eventos em pesquisa clínica: diretrizes para eliciar, gravar, e quantificar o MMN, P300 e N400. Audiol Commun Res 2015;20(02):VII-VIII

11 Cheng $\mathrm{CH}$, Chan PS, Hsieh YW, Chen KF. A meta-analysis of mismatch negativity in children with attention deficit-hyperactivity disorders. Neurosci Lett 2016;612:132-137

12 Schwade LF, Didoné DD, Sleifer P. Auditory Evoked Potential Mismatch Negativity in Normal-Hearing Adults. Int Arch Otorhinolaryngol 2017;21(03):232-238

13 Cheour M, Leppänen PHT, Kraus N. Mismatch negativity (MMN) as a tool for investigating auditory discrimination and sensory memory in infants and children. Clin Neurophysiol 2000;111(01):4-16

14 Alho K, Sainio K, Sajaniemi N, Reinikainen K, Näätänen R. Eventrelated brain potential of human newborns to pitch change of an acoustic stimulus. Electroencephalogr Clin Neurophysiol 1990;77 (02):151-155

15 Datta H, Shafer VL, Morr ML, Kurtzberg D, Schwartz RG. Electrophysiological indices of discrimination of long-duration, phonetically similar vowels in children with typical and atypical 
language development. J Speech Lang Hear Res 2010;53(03): 757-777

16 Koravand A, Jutras B, Lassonde M. Auditory event related potentials in children with peripheral hearing loss. Clin Neurophysiol 2013;124(07):1439-1447

17 Paul I, Bott C, Heim S, Wienbruch C, Elbert TR. Phonological but not auditory discrimination is impaired in dyslexia. Eur J Neurosci 2006;24(10):2945-2953

18 Huotilainen M, Lovio R, Kujala T, Tommiska V, Karma K, Fellman V. Could audiovisual training be used to improve cognition in extremely low birth weight children? Acta Paediatr 2011;100 (11):1489-1494

19 Soares AJC, Sanches SGG, Neves-Lobo IF, Carvallo RMM, Matas CG, Cárnio MS. Potenciais evocados auditivos de longa latência e processamento auditivo central em crianças com alterações de leitura e escrita: Dados preliminares. Int Arch Otorhinolaryngol 2011;15(04):486-491

20 Zhang Y, Zhang L, Shu H, et al. Universality of categorical perception deficit in developmental dyslexia: an investigation of Mandarin Chinese tones. J Child Psychol Psychiatry 2012;53(08):874-882

21 Noordenbos MW, Segers E, Serniclaes W, Mitterer H, Verhoeven L. Neural evidence of allophonic perception in children at risk for dyslexia. Neuropsychologia 2012;50(08):2010-2017

22 Chobert J, François C, Habib M, Besson M. Deficit in the preattentive processing of syllabic duration and VOT in children with dyslexia. Neuropsychologia 2012;50(08):2044-2055

23 van Zuijen TL, Plakas A, Maassen BA, Maurits NM, van der Leij A. Infant ERPs separate children at risk of dyslexia who become good readers from those who become poor readers. Dev Sci 2013;16 (04):554-563

24 Žarić G, Fraga González G, Tijms J, van der Molen MW, Blomert L, Bonte M. Reduced neural integration of letters and speech sounds in dyslexic children scales with individual differences in reading fluency. PLoS One 2014;9(10):e110337

25 Kaganovich N, Wray AH, Weber-Fox C. Non-linguistic auditory processing and working memory update in pre-school children who stutter: an electrophysiological study. Dev Neuropsychol 2010;35(06):712-736

26 Holopainen IE, Korpilahti P, Juottonen K, Lang H, Sillanpää M. Attenuated auditory event-related potential (mismatch negativity) in children with developmental dysphasia. Neuropediatrics 1997;28(05):253-256

27 Northens JL, Downs MP. Audição e perda auditiva em crianças, 5 ed, In: Audição na Infância. Guanabara Koogan; 2005:14

28 Jerger J. Clinical experience with impedance audiometry. Arch Otolaryngol 1970;92(04):311-324

29 Uwer R, von Suchodoletz W. Stability of mismatch negativities in children. Clin Neurophysiol 2000;111(01):45-52

30 Romero ACL, Capellini SA, Frizzo AC. Cognitive potential of children with attention deficit and hyperactivity disorder. Rev Bras Otorrinolaringol (Engl Ed) 2013;79(05):609-615

31 Haapala S, Niemitalo-Haapola E, Raappana A, et al. Effects of recurrent acute otitis media on cortical speech-sound processing in 2-year old children. Ear Hear 2014;35(03):e75-e83

32 Lepistö T, Soininen M, Ceponiene R, Almqvist F, Näätänen R, Aronen ET. Auditory event-related potential indices of increased distractibility in children with major depression. Clin Neurophysiol 2004;115(03):620-627

33 Jansson-Verkasalo E, Ceponiene R, Valkama M, et al. Deficient speech-sound processing, as shown by the electrophysiologic brain mismatch negativity response, and naming ability in prematurely born children. Neurosci Lett 2003;348(01):5-8

34 Kathmann N, Frodl-Bauch T, Hegerl U. Stability of the mismatch negativity under different stimulus and attention conditions. Clin Neurophysiol 1999;110(02):317-323
35 Yang FF, McPherson B, Shu H, Xiao Y. Central auditory nervous system dysfunction in infants with non-syndromic cleft lip and/or palate. Int J Pediatr Otorhinolaryngol 2012;76(01):82-89

36 Gomot M, Blanc R, Clery H, Roux S, Barthelemy C, Bruneau N. Candidate electrophysiological endophenotypes of hyper-reactivity to change in autism. J Autism Dev Disord 2011;41(06): 705-714

37 Bar-Haim Y, Marshall PJ, Fox NA, Schorr EA, Gordon-Salant S. Mismatch negativity in socially withdrawn children. Biol Psychiatry 2003;54(01):17-24

38 Ceponiene R, Haapanen ML, Ranta R, Näätänen R, Hukki J. Auditory sensory impairment in children with oral clefts as indexed by auditory event-related potentials. J Craniofac Surg 2002;13(04):554-566, discussion 567

39 Bishop DVM, Hardiman MJ, Barry JG. Lower-frequency eventrelated desynchronization: a signature of late mismatch responses to sounds, which is reduced or absent in children with specific language impairment. J Neurosci 2010;30(46): 15578-15584

40 Halliday LF, Barry JG, Hardiman MJ, Bishop DVM. Late, not early mismatch responses to changes in frequency are reduced or deviant in children with dyslexia: an event-related potential study. J Neurodev Disord 2014;6(01):21

41 Bruggemann JM, Stockill HV, Lenroot RK, Laurens KR. Mismatch negativity (MMN) and sensory auditory processing in children aged 9-12 years presenting with putative antecedents of schizophrenia. Int J Psychophysiol 2013;89(03):374-380

42 Gução ACB. Efeito da variação de frequência e duração do estímulo no registro do P300 e MMN [dissertação]. São Paulo, Universidade Estadual Paulista: Faculdade de Filosofia e Ciências de Marília; 2014:28-31

43 Korpilahti P, Krause CM, Holopainen I, Lang AH. Early and late mismatch negativity elicited by words and speech-like stimuli in children. Brain Lang 2001;76(03):332-339

44 Roggia SM, Colares NT. O mismatch negativity em pacientes com distúrbios do processamento auditivo (central). Rev Bras Otorrinolaringol 2008;74(05):705-711

45 Sussman E, Ceponiene R, Shestakova A, Näätänen R, Winkler I. Auditory stream segregation processes operate similarly in schoolaged children and adults. Hear Res 2001;153(1-2):108-114

46 Holdefer L. Análise da latência e amplitude dos potenciais evocados auditivos relacionados a eventos Mismatch Negativity em orelhas com e sem zumbido. [tese de doutorado]. Brasília: Universidade de Brasília; 2014

47 Duncan CC, Barry RJ, Connolly JF, et al. Event-related potentials in clinical research: guidelines for eliciting, recording, and quantifying mismatch negativity, P300, and N400. Clin Neurophysiol 2009;120(11):1883-1908

48 Jaramillo M, Paavilainen P, Näätänen R. Mismatch negativity and behavioural discrimination in humans as a function of the magnitude of change in sound duration. Neurosci Lett 2000; 290(02):101-104

49 Lindín M, Correa K, Zurrón M, Díaz F. Mismatch negativity (MMN) amplitude as a biomarker of sensory memory deficit in amnestic mild cognitive impairment. Front Aging Neurosci 2013;5:79

50 Buranelli G, Barbosa MB, Garcia CFD, et al. Verificação das respostas do Mismatch Negativity (MMN) em sujeitos idosos. Rev Bras Otorrinolaringol (Engl Ed) 2009;75(06):831-838

51 Melo A, Sleifer P, Rechia IC, Biaggio EPV. Potencial evocado auditivo cortical em neonates a termo e pré-termo: gênero e indicadores de risco para deficiência auditiva. Audiol Commun Res 2016;21:1-7

52 Barrett KA, Fulfs JM. Effect of gender on the mismatch negativity auditory evoked potential. J Am Acad Audiol 1998;9(06):444-451 